\section{Nurses' Hand Hygiene Knowledge, Attitude and Practice in Jimma University Medical Center, Jimma Town, Oromia Regional State, South West Ethiopia}

\author{
Abiru Neme*, Million Abera and Etsub Fasika \\ Jimma University, Institute of Health, School of Nursing and Midwifery, \\ Ethiopia
}

\begin{abstract}
Introduction: Hand washing is the simplest and most cost-effective intervention to reduce transmission of hospital acquired infections. Health care workers put themselves and their patients at risk when they fail to observe routine hygiene practices. Thus, this Study sought to assess the Nurses' Knowledge, Attitude and practice towards hand hygiene among Nurses working in Jimma University Medical Center, Jimma, South West Ethiopia.

Methods: An institution based cross-sectional study design was conducted from April 01-30, 2018. The study participants were all nurses working in Jimma University Medical Center during the study period. The data was collected using well developed questionnaires. Data analysis was done by hand and SPSS 20.0 version by considering both dependent and independent variables.

Results: The respondent rate produced was $96.20 \%$. The mean age of the respondents was $26.33 \pm 4.59$. Majority of the respondents were female $(60.44 \%)$, Nurses by profession $(82.11 \%)$, and had a professional experience of below 4 years $(67.43 \%)$. The number of nursing staffs who know the route of cross transmission of pathogens among patients and staffs in the medial center were 141
\end{abstract}

"Corresponding author: Abiru Neme, School of Nursing and Midwifery, Institute of Health, Jimma University, Ethiopia. Tel: 251-965240864; E-mail: abiruneme@ gmail.com

Citation: Neme A, Abera M, Fasika E [2020] Nurses' Hand Hygiene Knowledge, Attitude and Practice in Jimma University Medical Center, Jimma Town, Oromia Regional State, South West Ethiopia. J Community Med Public Health Care 7: 075 .

Received: April 01, 2020; Accepted: December 27, 2020; Published: December 31,2020

Copyright: $\odot 2020$ Neme A, et al. This is an open-access article distributed under the terms of the Creative Commons Attribution License, which permits unrestricted use, distribution, and reproduction in any medium, provided the original author and source are credited.
(64.68\%). The average knowledge related to hand hygiene actions was found to be $82.69 \%$ and knowledge the transmission of the microorganisms to the patient and healthcare workers was found to be $79.82 \%$. The overall knowledge of the practitioners in the hospital was found to be $65.54 \%$. The average attitude score for the ten attitude questions reported was $67.75 \%$. The overall score of hand hygiene practice among the respondents was $29.67 \%$.

Conclusion: All nurses do not have equal level of Knowledge attitude and practice. The knowledge level was moderate whereas attitude and practice level were poor. Training and mentoring should be provided for the nurses. Hand washing materials should also have to be fulfilled at wards/units in a sufficient amount.

Keywords: Attitude; hand; hygiene; Knowledge; Nurse; Practice

\section{Introduction}

Healthcare-associated infections are thought to be transmitted by the hands of Healthcare Providers through direct contact, mainly when the hands of nurses' transfer microorganisms between individuals or between individuals and the environmental reservoir [1,2].

In developed countries, HAI affects about $5-15 \%$ of hospitalized patients. The rate is higher among those in intensive care units (ICUs), between $937 \%[3,4]$. The incriminating organisms are often microbial isolates of Resistant to organisms. Eight Hospitals in Europe Link for Infection Control through Surveillance (HELICS) estimates millions of extra days of hospital stay and huge economic burden [5,6]. In the United States of America (USA), the estimated HAI incidence rate in the year 2004 was $4.5 \%$ with a fatality rate of $5 \%$ and a huge economic impact $[7,8]$.

According to WHO report in 2015 , approximately $70 \%$ of health care workers do not routinely practice hand hygiene. Health workers reporting misunderstandings about the relevance and importance of hand hygiene in everyday clinical practice [9].

Poor hand hygiene among healthcare workers was identified as one of the major causes of the infections. This study has revealed that nurses at the Lagos University Teaching Hospital have good knowledge of hand washing indicated by the finding of (83\%). This finding is similar to that reported among healthcare staff in ICU of a Multispecialty hospital in India (90\%), but higher than figures reported among nurses in Cairo in Elgalea Government Hospital (73.1\%), and Cleopatr a Private Hospital (72.7\%) [10-12]. It is also much better than the findings at the University of Port Harcourt Teaching Hospital (UPTH) in which more than half of the nurses (55.4\%) lack good knowledge of hand washing [13]. The high level of knowledge on hand washing by the respondents is not unexpected by virtue of their medical background. Also, working in tertiary center provides them a lot of opportunities to attend various seminars and training on infection control. More than $50 \%$ of the respondents in this study have attended such training/seminars and they had a significantly, better knowledge of hand washing than their counterparts who did not. 
Therefore, this study will provide insight on prevalence of hand hygiene compliance and associated factors among nurses working in Jimma University Medical Center.

In developing counties like Ethiopia where resources are very limited, compliance with standard precautions is a cost-effective strategy to prevent HAIs. The high level of knowledge on hand washing by the respondents is not unexpected by virtue of their medical background. Many studies on the practice of hand washing by nurses have reported low compliance rate [14-16]. At Emergency Unit of Royal Infirmary in United Kingdom in which the nurses had a better hand washing practice than the doctors in all the observed patient nurses interactions $(62.5 \%$ and $20.7 \%$ respectively [17]. As regards the variation in practice of hand washing, nurses were shown to have significantly Better hand washing practices than the doctors among healthcare providers (HCP) in Lagos University Teaching Hospital, South-West Nigeria [18].

In an observational study conducted among nurses in a tertiary hospital in Ghana, a hand washing complain cerate ranging from $9.2 \%$ to $57 \%$ among doctors and $9.6 \%$ to $54 \%$ among nurses was reported [19]. In the Egyptian study only $34 \%$ of the respondents had good practice of hand washing. In a similar study among nurses in ICU in a tertiary hospital in Nigeria, hand washing complain cerate of $53 \%$ was reported.

\section{Materials and Methods}

\section{Study area and period}

Jimma University Medical center (JUMC) is one of the oldest public hospitals in Ethiopia. It was established in 1930 E.C by Italian invaders for the service of their soldiers. Geographically, it is located in Jimma city $352 \mathrm{~km}$ southwest of Addis Ababa. After the withdrawal of the colonial occupants, it has been governed under the Ethiopian government by the name of "Ras Desta Damtew Hospital" and later "Jimma Hospital" during Dergue regime and currently Jimma University Medical Center. Currently it became the only teaching and referral hospital in the southwestern part of the country. The study was conducted from April 1 to 30/2018.

\section{Study design}

A prospective hospital based cross sectional study was conducted.

\section{Population}

Source population: All nurses who are practicing their profession in JUMC.

Study population: Sampled nurses who were working in JUMC during the study period and who fulfilled eligibility criteria.

\section{Eligibility criteria}

Inclusion criteria: All nurses who were working in JUMC during data collection.

Exclusion criteria: Those nurses who were seriously ill, who were on annual leave were not included in study population.

\section{Sample size and sampling techniques}

Sample size determination: The sample size required for the study was calculated using the formula to estimate a single population proportion.

$$
n=\frac{z^{2} p(1-p)}{d^{2}}
$$

Whereas $\mathrm{n}=$ desired sample size

$\mathrm{Z}=$ level of significance at $95 \%$ confidence interval

$\mathrm{p}=$ maximum expected proportion $(0.5)$

$\mathrm{d}=$ margin of error $(5 \%)$

$$
n=\frac{(1.96)^{2}(0.5)(0.5)}{(0.05)^{2}}=384
$$

Since the number of population is less than 10,000 , the sample size was adjusted. Therefore, the corrected sample size was;

$$
n_{f}=\frac{n}{1+\frac{n}{N}}
$$

Where, $\mathrm{n}_{\mathrm{f}}=$ desired sample size

$\mathrm{n}=$ sample from infinite population (205)

$\mathrm{N}=$ population size 489 (total number of Nurses)

$$
n_{f}=\frac{384}{1+\frac{384}{489}}=215
$$

And $10 \%$ non-respondent was added to the corrected sample size, and the final sample size was:

$$
215+(215 \times 0.1)=236.5 \approx 237
$$

Sampling technique: The study participants were selected by using stratified sampling technique (the stratum was each working unit or ward). Then simple random sampling technique were employed to select proportionate sample from each stratum.

Surgical Ward $=60$ nurses

$$
\frac{60}{489} \times 237=29.08 \approx 29 \text { nurses }
$$

Medical ward $=67$ nurses

$$
\frac{67}{489} \times 237=33.44 \approx 33 \text { nurses }
$$

ICU $($ Adult \& Neonatal $)=$ nurses

$$
\frac{59}{489} \times 237=28.60 \approx 29 \text { nurses }
$$

Pediatrics $=59$ nurses

$$
\frac{59}{489} \times 237=28.60 \approx 29 \text { nurses }
$$

Gynecology $=36$ nurses

$$
\frac{36}{489} \times 237=17.44 \approx 17 \text { nurses }
$$

Maternity $=69$ nurses

$$
\frac{69}{489} \times 237=33.44 \approx \text { 33nurses }
$$

Operation room $=64$ nurses

$$
\frac{64}{489} \times 237=31.02 \approx 31 \text { nurses }
$$

$\mathrm{OPD}=42$ nurses

$$
\frac{42}{489} \times 237=20.36 \approx 2 \text { nurses }
$$


Ophthalmology $=33$ nurses

$$
\frac{33}{489} \times 237=15.99 \approx 16 \text { nurses }
$$

\section{Study variables}

Dependent variable: Hand hygiene Knowledge, Attitude and Practice

\section{Independent variables}

- Age

- Sex

- Marital status

- Monthly income

- Job title

- Level of qualification

- Training on infection prevention

- Assigned place/ward

- The components/materials used for hand hygiene

- Hand washing habit

- Years of service

\section{Data collection procedure and quality assurance}

The data was collected using well developed and pre-tested semistructured questionnaires that is adapted from the review of literatures and similar studies from Ethiopian national infection prevention and patient safety guideline and other literatures [20]. Three trained second year BSc. nursing students were assigned as data collection facilitator.

Data was collected by three data collection facilitators after training was given to them. The information was collected after getting permission from JUMC. During the process of data collection, the overall activity was supervised by principal investigator and appropriate correction was made. Before undertaking the data collection, the data collection instrument was pre-tested on $5 \%$ of the sample size (12 Nurses) who were working in Shenen Gibe Hospital. Any constraint was corrected promptly [21].

\section{Data processing and analysis}

Data was processed and analyzed using different materials like scientific calculator, pen, pencil, Microsoft excel, tally sheet and descriptive statistics like frequency distribution, mean, standard deviation was used for continues variables to examine the subjects' characteristics. Simple frequency tables and graphs were used to present the analyzed data [22].

\section{Ethical consideration}

Ethical clearance was obtained from the college of health sciences CBE office and this was communicated to JUMC to get permission. Permission and verbal consent was obtained from each respondent and confidentiality was assured before conducting data collection process. All information that was obtained from the individual was treated confidential and was not used to the determinant of the subject and for this reason their names was not be written on the questionnaire.

\section{Results}

\section{Socio-demographic characteristics of respondents}

The respondent rate was $96.20 \%$. As showed in (Table 1), the mean age of the respondents was $26.33 \pm 4.59$. Majority of the respondents were female $(60.44 \%)$, single $(62.39 \%)$, had Bachelor of Degree (53.21\%), Nurses by profession $(82.11 \%)$, and had a professional experience of below 4 years $(67.43 \%)$.

\begin{tabular}{|c|c|c|c|c|}
\hline $\mathbf{S} / \mathbf{N}$ & Variable & Number & $\%$ & Remarks \\
\hline \multirow[t]{6}{*}{1} & Age (in year) & & & \multirow{6}{*}{$\begin{array}{c}\text { Mean }=26.33 \\
\mathrm{SD}=4.591\end{array}$} \\
\hline & $20-24$ & 91 & 41.74 & \\
\hline & $25-29$ & 84 & 38.53 & \\
\hline & $30-34$ & 27 & 12.39 & \\
\hline & $35-39$ & 11 & 5.05 & \\
\hline & Above 39 & 5 & 2.29 & \\
\hline \multirow[t]{3}{*}{2} & Sex & & & \\
\hline & Male & 86 & 60.55 & \\
\hline & Female & 132 & 39.45 & \\
\hline \multirow[t]{4}{*}{3} & Marital Status & & & \\
\hline & Single & 136 & 62.39 & \\
\hline & Married & 78 & 35.78 & \\
\hline & $\begin{array}{l}\text { Separated (Divorced, } \\
\text { widow) }\end{array}$ & 4 & 1.83 & \\
\hline \multirow[t]{4}{*}{4} & Qualification & & & \\
\hline & Diploma & 97 & 44.50 & \\
\hline & Degree & 116 & 53.21 & \\
\hline & MSc and Above & 5 & 2.29 & \\
\hline \multirow[t]{4}{*}{5} & Profession & & & \\
\hline & Nurse & 179 & 82.11 & \\
\hline & Auxiliary nurse & 0 & 0 & \\
\hline & Midwife & 39 & 17.89 & \\
\hline \multirow[t]{5}{*}{6} & Years of Experience & & & \\
\hline & $0-4$ & 147 & 67.43 & \\
\hline & $5-9$ & 57 & 26.15 & \\
\hline & $10-14$ & 11 & 5.05 & \\
\hline & Above 14 & 3 & 1.38 & \\
\hline \multirow[t]{4}{*}{7} & $\begin{array}{l}\text { Monthly Income (in } \\
\text { birr) }\end{array}$ & & & \\
\hline & 2000-3000 & 49 & 22.48 & \\
\hline & $3001-4000$ & 52 & 23.85 & \\
\hline & Above 4000 & 117 & 53.67 & \\
\hline \multirow[t]{10}{*}{8} & Department/unit & & & \\
\hline & Surgical Ward & 26 & 11.93 & \\
\hline & Medical ward & 30 & 13.76 & \\
\hline & Pediatrics & 26 & 11.93 & \\
\hline & ICU (Adult \& Neonatal) & 27 & 12.39 & \\
\hline & Gynecology & 17 & 7.8 & \\
\hline & Maternity & 30 & 13.76 & \\
\hline & Operation room & 29 & 13.30 & \\
\hline & OPD & 18 & 8.26 & \\
\hline & Ophthalmology & 15 & 6.87 & \\
\hline
\end{tabular}

Table 1: Socio-demographic characteristics of pregnant women attending ANC in JUMC. 


\section{Knowledge of respondents towards Hand Hygiene}

As indicated in (Table 2), the number of nursing staffs who know the route of cross transmission of pathogens among patients and staffs in the medial center were $141(64.68 \%)$; and the rest did not respond correctly. Regarding the source of micro-organisms for nosocomial infection, about $74.91 \%(\mathrm{n}=74.31 \%)$ respond correctly. Knowledge related to hand hygiene actions that prevent the transmission of the microorganisms to the patient and healthcare workers was assessed; accordingly, the average knowledge was found to be $82.69 \%$ and $79.82 \%$ respectively [23].

\begin{tabular}{|c|c|c|c|c|}
\hline $\mathbf{S} / \mathbf{N}$ & Knowledge based questions & No. & $\%$ & Remarks \\
\hline $\mathrm{K} 1$ & $\begin{array}{l}\text { Route of cross transmission of pathogens among pa- } \\
\text { tients in hospital (Health-care workers' hands when } \\
\text { not clean) }\end{array}$ & 141 & 64.68 & \\
\hline $\mathrm{K} 2$ & $\begin{array}{l}\text { Source of organisms for nosocomial infections } \\
\text { (Germs already present on or within the patient) }\end{array}$ & 165 & 74.31 & \\
\hline \multirow[t]{5}{*}{ K3 } & $\begin{array}{l}\text { Hand hygiene actions which prevent transmission of } \\
\text { organisms to patients }\end{array}$ & & & \\
\hline & Before touching a patient (yes) & 198 & 90.83 & \\
\hline & Immediately after body fluid exposure (Yes) & 177 & 81.19 & \\
\hline & Before a clean / aseptic procedure (yes) & 159 & 72.94 & \\
\hline & $\begin{array}{l}\text { After exposure to immediate surroundings of the } \\
\text { patient (No) }\end{array}$ & 187 & 85.78 & \\
\hline \multirow[t]{5}{*}{ K4 } & $\begin{array}{l}\text { Hand hygiene actions which prevent transmission of } \\
\text { organisms to health care workers }\end{array}$ & & & \\
\hline & After touching a patient (yes) & 205 & 94.04 & \\
\hline & Immediately after body fluid exposure (yes) & 190 & 87.16 & \\
\hline & Before a clean / aseptic procedure (yes) & 112 & 51.38 & \\
\hline & $\begin{array}{l}\text { After exposure to immediate surroundings of the } \\
\text { patient (no) }\end{array}$ & 189 & 86.70 & \\
\hline \multirow[t]{5}{*}{ K5 } & $\begin{array}{l}\text { True statement on alcohol-based hand rub and hand } \\
\text { washing with soap and water }\end{array}$ & & & \\
\hline & $\begin{array}{l}\text { Hand rubbing is more rapid for hand cleansing than } \\
\text { handwashing(True) }\end{array}$ & 152 & 69.72 & \\
\hline & $\begin{array}{l}\text { Hand rubbing causes skin dryness more than hand } \\
\text { washing (False) }\end{array}$ & 155 & 71.10 & \\
\hline & $\begin{array}{l}\text { Hand rubbing is more effective against germs than } \\
\text { hand washing (False) }\end{array}$ & 118 & 54.13 & \\
\hline & $\begin{array}{l}\text { Hand washing and hand rubbing are to be performed } \\
\text { in sequence (False) }\end{array}$ & 117 & 53.67 & \\
\hline K6 & $\begin{array}{l}\text { Minimal time needed for alcohol based handrubs } \\
(20 \mathrm{sec})\end{array}$ & 66 & 30.28 & \\
\hline \multirow[t]{7}{*}{ K7 } & Type of hand hygiene method in various situations & & & \\
\hline & before palpation of abdomen (Rubbing) & 70 & 32.11 & \\
\hline & before giving injections (Rubbing) & 57 & 26.15 & \\
\hline & after emptying bed pan (washing) & 151 & 69.27 & \\
\hline & $\begin{array}{l}\text { after removing examination gloves (Rubbing/Wash- } \\
\text { ing) }\end{array}$ & 147 & 67.43 & \\
\hline & after making patients bed (Rubbing) & 69 & 31.65 & \\
\hline & after visible exposure to blood (Washing) & 104 & 47.71 & \\
\hline \multirow[t]{6}{*}{ K8 } & Actions to be avoided during hand hygiene & & & \\
\hline & wearing jewelry (yes) & 167 & 76.61 & \\
\hline & artificial finger nails (yes) & 203 & 93.12 & \\
\hline & regular use of hand creams (No) & 174 & 79.82 & \\
\hline & presence of damaged skin (yes) & 99 & 45.41 & \\
\hline & Average & & 65.54 & \\
\hline
\end{tabular}

Table 2: Assessment of Nurses' Knowledge toward Hand Hygiene inJUMC, Jimma town.
Correctly responded $62.16 \%$ of the respondents correctly answered about alcohol-based hand rub and hand washing with soap and water; and only $30.28 \%$ of the study subjects responded the minimal time needed for alcohol-based hand rubs, i.e., 20 seconds. The average correct response for types of hand hygiene for various situations and actions that should be avoided during hand hygiene was $45.72 \%$ and $73.74 \%$ respectively. The overall knowledge of the practitioners in the hospital was found to be $65.54 \%$.

\section{Attitude of the respondents towards hand hygiene}

As showed in (Table 3), items for which respondents take positive/good attitude include: I am tasked to act as a model for other healthcare personnel about hand hygiene 189 (86.7\%); Execution of hand hygiene may reduce mortality of patients under the recommended conditions 186 (85.32\%); Execution of hand hygiene may reduce the related medical costs to Nosocomial infections under the recommended conditions 194 (88.99\%); The hand hygiene is assumed as a habit in my personal life 189 (86.7\%); I think I have potential to change poor performances regarding hand hygiene in my workplace 171 (78.44\%). On the other hand, items for which the nurses score Negative/poor attitude include: It is more important for me to fulfill perfectly my tasks than doing hand hygiene when the given ward is busy 86 (39.45\%); I could not always do hand hygiene under the recommended situations because of preference of my patients' requirements $123(56.42 \%)$; and the existing infectious diseases in health care-giving environment may threaten my life and occupation $97(44.50 \%)$. The average attitude score for the ten attitude questions reported was $67.75 \%$.

\section{Practice of the Nursing staffs towards Hand Hygiene}

Five major hand hygiene practicing points were considered. $72.82 \%$ of the study subjects do not clean their hands before touching patient. Before cleaning or applying anti-septic procedures on a patient only $13.99 \%$ of the respondents practiced hand hygiene. After Body Fluid Exposure Risk, those clean their hands were two third (66.59\%) of the respondents. With regard to complying to hand hygiene after touching patient units, only few $(14.15 \& \%)$ of the study population. The other hand hygiene practice area respondents were requested to report was hand washing after touching patient surroundings; the study identified only $6.53 \%$ of the respondents clean their hands. Generally, the overall score of hand hygiene practice among the respondents was $29.67 \%$ (Table 4 ).

\section{Discussion}

Assessing the knowledge, practices and attitudes for health care workers may help in recognizing the factors that affect their compliance with hand hygiene. $64.68 \%$ and $74.91 \%$ of the respondents knew that route of cross transmission of pathogens among patients and staffs in the medical center and the source of micro-organisms for nosocomial infection respectively, this is low as compared to India which is $100 \%$ on the route of transmission and $94.6 \%$ on the source of pathogens for nosocomial infection but higher than that of Sir Lanka which is $26.9 \%$ for source of pathogens. Knowledge on Hand hygiene actions which prevent transmission of organisms to patients and health care workers was assessed and found to be $81.25 \%$. This study is almost similar to that of Sir Lanka (79.69) and India (80.1\%) [24,25]. Those who have the minimal time for alcohol hand rubbing were only $30.28 \%$ of the study subjects which might be associated with the absence of hand rub alcohol. 
Citation: Neme A, Abera M, Fasika E [2020] Nurses' Hand Hygiene Knowledge, Attitude and Practice in Jimma University Medical Center, Jimma Town, Oromia Regional State, South West Ethiopia. J Community Med Public Health Care 7: 075.

\begin{tabular}{|c|c|c|c|c|c|}
\hline \multirow{2}{*}{$\mathbf{S} / \mathbf{N}$} & \multirow{2}{*}{ Attitude based questions } & Agree \& strongly agree & No comment & Disagree \& strongly disagree & \multirow{2}{*}{ Remarks } \\
\hline & & No. (\%) & No. (\%) & No. (\%) & \\
\hline A1 & $\begin{array}{l}\text { I am tasked to act as a model about hand hygiene for other healthcare } \\
\text { personnel. }\end{array}$ & $189(86.7)$ & $27(12.39)$ & $2(0.92)$ & \\
\hline $\mathrm{A} 2$ & $\begin{array}{l}\text { It is more important for me to fulfill perfectly my tasks than doing hand } \\
\text { hygiene when the given ward is busy. }\end{array}$ & $95(43.58)$ & $37(16.97)$ & $86(39.45)$ & \\
\hline A3 & $\begin{array}{l}\text { Execution of hand hygiene may reduce mortality of patients under the } \\
\text { recommended conditions. }\end{array}$ & $186(85.32)$ & $28(12.84)$ & $4(1.83)$ & \\
\hline A4 & $\begin{array}{l}\text { Execution of hand hygiene may reduce the related medical costs to Noso- } \\
\text { comial infections under the recommended conditions }\end{array}$ & $194(88.99)$ & $16(7.34)$ & $8(3.67)$ & \\
\hline A5 & $\begin{array}{l}\text { I could not always do hand hygiene under the recommended situations } \\
\text { because of preference of my patients' requirements }\end{array}$ & $72(33.03)$ & $23(10.55)$ & $123(56.42)$ & \\
\hline A6 & $\begin{array}{l}\text { Prevention from the acquired infections is deemed as one of valuable roles } \\
\text { for personnel of healthcare services. }\end{array}$ & $192(88.07)$ & $22(10.09)$ & $4(1.83)$ & \\
\hline A7 & $\begin{array}{l}\text { I think one could follow the medical service officials in order to make } \\
\text { decision for execution and or nonexecution of hand hygiene }\end{array}$ & $157(72.02)$ & $9(4.13)$ & $52(23.85)$ & \\
\hline A8 & $\begin{array}{l}\text { The existing infectious diseases in health care-giving environment may } \\
\text { threaten my life and occupation }\end{array}$ & $77(35.32)$ & $44(20.18)$ & $97(44.50)$ & \\
\hline A9 & $\begin{array}{l}\text { I think I have potential to change poor performances regarding hand hy- } \\
\text { giene in my workplace. }\end{array}$ & $171(78.44)$ & $28(12.84)$ & $19(8.72)$ & \\
\hline \multirow[t]{2}{*}{ A 10} & The hand hygiene is assumed as a habit in my personal life. & $189(86.7)$ & $27(12.39)$ & $2(0.92)$ & \\
\hline & Average & 147.7 & 67.75 & & \\
\hline
\end{tabular}

Table 3: Assessment of Nurses' attitude toward Hand Hygiene in JUMC, Jimma town.

\begin{tabular}{|c|c|c|c|c|}
\hline $\mathbf{S} / \mathbf{N}$ & Items & Yes & No & \multirow{2}{*}{ Remarks } \\
\hline P1 & Before touching patient & No. $(\%)$ & No. $(\%)$ & \\
\hline 1 & Before shaking hand. & $65(29.82)$ & $153(70.81)$ & \\
\hline 2 & Before assisting a patient in personal care activities to move, to take a bath, to gate dressed. & $52(23.85)$ & $166(76.15)$ & \\
\hline 3 & Before delivering care and other non-intensive treatment: applying oxygen mask, giving a massage; & $82(37.61)$ & $136(62.39)$ & \\
\hline 4 & $\begin{array}{l}\text { Before performing a physical non-intensive examination: taking pulse, blood pressure, chest ausculta- } \\
\text { tion, recording ECG }\end{array}$ & $38(17.43)$ & $180(82.57)$ & \\
\hline $\mathrm{P} 2$ & Before clean/ Aseptic procedure & & & \\
\hline 5 & $\begin{array}{l}\text { Before brushing the patient teeth, instilling eye drops, performing a digital vaginal or rectal examination, } \\
\text { examining mouth, nose, ear with or without instrument, inserting suppository / pessary / suctioning } \\
\text { mucosa. }\end{array}$ & $28(12.84)$ & $190(87.16)$ & \\
\hline 6 & $\begin{array}{l}\text { Before dressing wound with or without instrument, applying ointment on vesicle, making a percutaneous } \\
\text { injection/puncture }\end{array}$ & $46(21.10)$ & $172(78.90)$ & \\
\hline 7 & $\begin{array}{l}\text { Before inserting an invasive medical device (nasal canula, nasogastric tube, endotracheal tube, urinary } \\
\text { probe percutaneous catheter, drainage) }\end{array}$ & $19(8.72)$ & $199(91.28)$ & \\
\hline 8 & Before preparing a food, medication, pharmaceutical product, sterile material & $29(13.30)$ & $189(86.70)$ & \\
\hline $\mathrm{P} 3$ & After Body Fluid Exposure Risk & & & \\
\hline 9 & When the contact with mucous membrane and with non-intact skin ends & $96(44.04)$ & $122(55.96)$ & \\
\hline 10 & $\begin{array}{l}\text { After per cutaneous injection or puncture, after inserting an invasive medical device (vascular access, } \\
\text { catheter tube, drains etc.) }\end{array}$ & $152(69.72)$ & $66(30.28)$ & \\
\hline 11 & After disrupting and opening an invasive circuit & $132(60.55)$ & $86(39.45)$ & \\
\hline 12 & After removing an invasive medical device & $129(59.17)$ & $89(40.83)$ & \\
\hline 13 & After removing an any form of marital offering protection & $203(93.12)$ & $15(6.88)$ & \\
\hline 14 & $\begin{array}{l}\text { After handling a sample containing organic matter, after cleaning any contaminated surface and soiled } \\
\text { material (soiled bed linen, denture, instrument, urinal, bed pan lavatories etc.) }\end{array}$ & $159(72.94)$ & $59(27.06)$ & \\
\hline $\mathrm{P} 4$ & After touching patient unit & & & \\
\hline 15 & Before shaking hand & $25(11.47)$ & $193(88.53)$ & \\
\hline 16 & After assisting a patient in personal care activates to move, to take a bath, to get dressed & $39(17.89)$ & $179(82.11)$ & \\
\hline 17 & $\begin{array}{l}\text { After delivering care and other non-intensive treatment: changing bed linen as the patient is in applying } \\
\text { oxygen mask, giving massage }\end{array}$ & $44(20.18)$ & $174(79.82)$ & \\
\hline 18 & $\begin{array}{l}\text { After performing physical non-intensive examination: taking pulse, blood pressure, chest auscultation, } \\
\text { recording ECG }\end{array}$ & $18(8.26)$ & $200(91.74)$ & \\
\hline
\end{tabular}




\begin{tabular}{|c|l|c|c|}
\hline P5 & After touching patient surroundings & & \\
\hline 19 & $\begin{array}{l}\text { After an activity involving physical contact with patient immediate environment: changing bed linen } \\
\text { with the patient out of the bed. }\end{array}$ & $34(15.60)$ & $12(5.50)$ \\
\hline 20 & Holding a bed trail, clearing a bed table & $18(8.26)$ & $206(94.50)$ \\
\hline 21 & After a care activity: adjusting perfusion speed, clearing a monitoring alarm & $3(1.38)$ & $215(98.40)$ \\
\hline 22 & $\begin{array}{l}\text { After other contact with surface or inanimate objects: learning against a bed, learning against a night } \\
\text { table/ beside table. }\end{array}$ & $29.67 \%$ & $70.33 \%$ \\
\hline & Average & & 200 \\
\hline
\end{tabular}

Table 4: Assessment of Nurses’ Practice toward Hand Hygiene in JUMC, Jimma town.

In a study conducted in India (24) and Sir Lanka the figure is even below $(24.7 \%$ and $23 \%$ respectively).Regarding the overall knowledge level of nurses (65.54\%) is in line with India (63.1\%); and $77 \%$ in Sir Lanks. Rawan Aledeilah et al. reported that majority of the health care professionals in Arar city, Saudi Arabia had better knowledge (90.5\%). This difference may rise form difference in study setting [26].

The results of our study indicated that most of nurses $(147,67.75 \%)$ took positive attitude toward hand hygiene. A study conducted by Sharif et al. showed that the nurses also have positive attitude towards hand hygiene with over all attitude of $70.5 \%$. Another study conducted by Arthi E et al., showed that the overall attitude of the respondents towards hand hygiene was not satisfactory $14 \%$; whereas higher level $(81 \%)$ seen in a study conducted by Aledeilah et al. On the other hand, poor attitude level was obtained in $87 \%$ in a study conducted by Ariyarante et al. [27]. The difference in level of attitude may be associated with sample size. The major areas of attitude with higher score were: I am tasked to act as a model about hand hygiene for other healthcare personnel, Execution of hand hygiene may reduce mortality of patients under the recommended conditions, Prevention from the acquired infections is deemed as one of valuable roles for personnel of healthcare services, I think one could follow the medical service officials in order to make decision for execution and or nonexecution of hand hygiene, I think I have potential to change poor performances regarding hand hygiene in my workplace and The hand hygiene is assumed as a habit in my personal life. Similar outcome was seen in a study conducted by Sharif et al. [28].

The findings of this study indicated that most of nurses had very poor practice of hand hygiene that may represent holding appropriate training courses in these hospitals. $72.82 \%$ of the study subjects do not clean their hands before touching patient. Before cleaning or applying anti-septic procedures on a patient only $13.99 \%$ of the respondents practiced hand hygiene [29]. After Body Fluid Exposure Risk, those clean their hands were two third $(66.59 \%)$ of the respondents. With regard to complying to hand hygiene after touching patient units, only few $(14.15 \%)$ of the study population. The other hand hygiene practice area respondents were requested to report was hand washing after touching patient surroundings; the study identified only $6.53 \%$ of the respondents clean their hands. Generally, the overall score of hand hygiene practice among the respondents was $29.67 \%$. Arthi E et al. indicated that the practice of good hand hygiene practice was $5 \%$ among nurses. As reported by Aledelilah et al. $75.9 \%$ of nurses practice hand hygiene moderately. Additionally, Ariyaratne et al. stated that $38 \%$ of nurses poorly complied with Hand hygiene. Better practice i.e. 87.5 and $62.1 \%$ was reported by Sharif et al. and
Neir et al. The poor hand hygiene practice in this study may be associated commitment of the nurses, lack of training, availability of hand washing materials such as alcohol-based hand rubs, water, soap.

\section{The strength and weakness of the study}

Strength of the study: This study could provide a better specific gaps and strength that will be used for intervention unlike other methods of questionnaire design; these was after it has been contextualized with the study setting and source population. Thus, this study is also come up with better reliable information.

The weakness of the study: This study is expected to be prone for limitation of cross-sectional survey (temporal relationship). The diversity of the nurses (study participants) was not duly acknowledged. Thus, the intent of their diversity in terms of religion, ethnicity, and address (previous residence) could have an effect on the questionnaire development; these is because the explicit wisdom, values or culture of a given ethnic group, religion or previous environment are expected to have some kind of influence on current decisions related to hand hygiene in general.

\section{Conclusion}

There is a wide range gap in knowledge among nurses practicing in the medical center. Hand washing practice before cleaning or applying antiseptic procedure on a patient, minimal time of applying hand rub alcohol, type of hand hygiene method used in different situations, and actions that should be avoided during hand hygiene practice were areas of lower knowledge level.

Majority of the nurses had positive attitude towards hand hygiene. The practice was poor, except for items: hand hygiene practice after per cutaneous injection or puncture, after inserting an invasive medical device (vascular access, catheter tube, drains etc.), After disrupting and opening an invasive circuit, after removing an invasive medical device, after removing an any form of marital offering protection (napkin, dressing, gauze, sanitary towel etc. and after handling a sample containing organic matter, after cleaning any contaminated surface and soiled material (soiled bed linen, denture, instrument, urinal, bed pan lavatories etc.)

\section{Recommendation}

Jimma University Medical center in collaboration with school of Nursing and Midwifery should plan for training on good hand hygiene practice and infection prevention with continuous monitoring and performance feedback to encourage them to follow correct hand hygiene practice. Supervision should also have conducted by Nursing 
Citation: Neme A, Abera M, Fasika E [2020] Nurses' Hand Hygiene Knowledge, Attitude and Practice in Jimma University Medical Center, Jimma Town, Oromia Regional State, South West Ethiopia. J Community Med Public Health Care 7: 075.

Director of the medical center. Hand washing materials should be availed at every nurse practice area in a sufficient amount. Future studies should also be conducted to determine the factors responsible for these gaps.

\section{Availability of Data and Materials}

The spreadsheet data supporting the findings of this work is available at the hands of the corresponding author.

\section{Ethics Statement}

All procedures performed in studies involving human participants were in accordance with the ethical standards of the institutional and/or national research committee and with the declaration and its later amendments or comparable ethical standards. Before the commencement of the study, ethical approval was secured from the Jimma University Ethical Review Board. Written informed consent was obtained from all individual participants included in the study.

\section{Consent}

The purpose of the study was explained to the study participants at the time of data collection and verbal consent was secured from each participant before the start of data collection. Confidentiality was ensured by not including names or other identifiers in the data collection tool. The right of the participants to refuse participation or not to answer any of the questions was respected.

\section{Competing Interests}

Authors' declared that they have no conflict of interests. Jimma University covered only the survey cost for this study and there is no any funding organization.

\section{Authors' Contribution}

Etsub Fasika and Million Abera conceived and designed the protocol. Million Abera and Etsub Fasika, contributed on data analysis, and checked the draft. Abiru Neme and Million Abera prepared manuscript. Million Abera and Abiru Neme read and approved the final paper.

\section{Acknowledgements}

We would like to thank the Jimma University Medical Center as well as the administrative staffs for all the help and support given for us during the data collection period. We also thank Jimma university institute of health for permitting us to conduct this study.

\section{References}

1. Pittet D, Hugonnet S, Harbarth S, Mourouga P, Sauvan V, et al. (2000) Effectiveness of a hospital-wide programme to improve compliance with hand hygiene. The Lancet 356: 1307-1312.

2. Albert RK, Condie F (1981) Hand-washing patterns in medical intensive-care units. N Engl J Med 304: 1465-1466.

3. Vincent JL (2003) Nosocomial infections in adult intensive-care units. The lancet 361: 2068-2077.

4. Allegranzi B, Pittet D (2009) Role of hand hygiene in healthcare-associated infection prevention. J Hosp Infect 73: 305-315.

5. Pittet D, Allegranzi B, Storr J, Nejad SB, Dziekan G, et al. (2008) Infection control as a major World Health Organization priority for developing countries. J Hosp Infect 68: 285-292.
6. Dumpis U, Balode A, Vigante D, Narbute I, Valinteliene R, et al. (2003) Prevalence of nosocomial infections in two Latvian hospitals. Euro surveillance: bulletin Europeen sur les maladies transmissibles=European communicable disease bulletin 8: 73-8.

7. Sutter ST, Pargerr H, Widmer AF (2010) Hand hygiene in the intensive care unit. Crit Care Med 38: 299-305.

8. Azzam R, Dramaix M (2001) A one-day prevalence survey of hospital-acquired infections in Lebanon. J Hosp Infect 49: 74-8.

9. Organization WH, Control RfIT (2008) WHO report on the global tobacco epidemic, 2008: the MPOWER package: World Health Organization.

10. Pittet D, Mourouga P, Perneger TV (1999) Compliance with handwashing in a teaching hospital. Ann internal Med 130: 126-130.

11. Stone PW, Braccia D, Larson (2005) Systematic review of economic analyses of health care-associated infections. Am J Infect Control 33: 501-509.

12. Allegranzi B, Pittet D (2007) Healthcare-associated infection in developing countries: simple solutions to meet complex challenges. Infect Control Hosp Epidem 28: 1323-1327.

13. Sharma R, Sharma M, Koushal V (2012) Hand washing compliance among healthcare staff in Intensive Care Unit (ICU) of a Multispecialty Hospital of North India. J Hosp Admin 1: 27.

14. Mathai AS, George SE, Abraham J (2011) Efficacy of a multimodal intervention strategy in improving hand hygiene compliance in a tertiary level intensive care unit. Ind J Critical Care Med 15: 6.

15. Elaziz KA, Bakr IM (2009) Assessment of knowledge, attitude and practice of hand washing among health care workers in Ain Shams University hospitals in Cairo. J Prev Med Hyg 50: 19-25.

16. Tobi K, K EN (2013) Hand washing practices and compliance amongHealth care workers in intensive care unit of a tertiary hospital in Nigeria. Niger Medic Pract 63.

17. Rumgay S, Macdonald S, Robertson C (1984) Hand-washing patterns and infection control in the accident and emergency department. Arch Emerg Med 1:157-159.

18. Ekwere TA, Okafor IP (2013) Hand hygiene knowledge and practices among healthcare providers in a tertiary hospital, south west, Nigeria. Int J Infect Control 9.

19. Yawson AE, Hesse AA (2013) Hand hygiene practices and resources in a teaching hospital in Ghana. The Journal of Infection in Developing Countries 7:338-347.

20. Nair SS, Hanumantappa R, Hiremath SG, Siraj MA, Raghunath P (2014) Knowledge, attitude, and practice of hand hygiene among medical and nursing students at a tertiary health care centre in Raichur, India. ISRN Prev Med.

21. Organization WH (2004) Practical Guidelines for Infection Control in Health Care Facilities SEARO and WPRO Publication No 41. New Delhi: India and Manila: The Philippines.

22. Pittet D, Allegranzi B, Storr J, Donaldson L (2006) Clean care is safer care': the global patient safety challenge 2005-2006. In J Infect Dis 10: 419-424.

23. Ansari S, Gupta P, Jais M, Nangia S, Gogoi S, et al. (2015) Assessment of the knowledge, attitude and practices regarding hand hygiene amongst the healthcare workers in a tertiary health care centre. Int J Pharma Res Health Sci 3:720-726.

24. Arthi E, Abarna V, Bagyalakshmi R, Anitharaj M, Vijayasree S (2016) Assessment of Knowledge, Attitude and Practice of Hand Hygiene among Nursing and Medical Students in a Tertiary Care Hospital in Puducherry, India. Int J Contemporary Med Res 3. 
25. Ariyaratne M, Gunasekara T, Weerasekara M, Kottahachchi J, Kudavidanage B, et al. (2013) Knowledge, attitudes and practices of hand hygiene among final year medical and nursing students at the University of Sri Jayewardenepura. Sri Lankan JInfect Dis 3:15-25.

26. Aledeilah RDI, El-Fetoh NMA, Albaker A, Aljabbab AA, Alkhannani SJ, et al. (2018) Assessment of Knowledge, Attitude and Practice of Hand Hygiene among Health Care Workers in Arar City, Saudi Arabia. Egypt J Hosp Med 70: 491-498.

27. Ariyaratne M, Gunasekara T, Weerasekara M, Kottahachchi J, Kudavidanage B, et al. (2015) Knowledge, attitudes and practices of hand hygiene among final year medical and nursing students at the University of Sri Jayewardenepura. Sri Lanka J Infect Dis 3.
28. Sharif A, Arbabisarjou A, Balouchi A, Ahmadidarrehsima S, Kashani HH (2016) Knowledge, Attitude, and Performance of Nurses toward Hand Hygiene in Hospitals. Glob J Health Sci $8: 57$.

29. Christiaens G, Barbier C, Mutsers J, Warnotte J, De Mol P, et al. (2006) Hand hygiene: first measure to control nosocomial infection. Revue medicale de Liege 61: 31-36. 


\section{Hif}

Advances In Industrial Biotechnology | ISSN: 2639-5665

Advances In Microbiology Research | ISSN: 2689-694X

Archives Of Surgery And Surgical Education | ISSN: 2689-3126

Archives Of Urology

Archives Of Zoological Studies | ISSN: 2640-7779

Current Trends Medical And Biological Engineering

International Journal Of Case Reports And Therapeutic Studies | ISSN: 2689-310X

Journal Of Addiction \& Addictive Disorders | ISSN: 2578-7276

Journal Of Agronomy \& Agricultural Science | ISSN: 2689-8292

Journal Of AIDS Clinical Research \& STDs | ISSN: 2572-7370

Journal Of Alcoholism Drug Abuse \& Substance Dependence | ISSN: 2572-9594

Journal Of Allergy Disorders \& Therapy | ISSN: 2470-749X

Journal Of Alternative Complementary \& Integrative Medicine | ISSN: 2470-7562

Journal Of Alzheimers \& Neurodegenerative Diseases | ISSN: 2572-9608

Journal Of Anesthesia \& Clinical Care | ISSN: 2378-8879

Journal Of Angiology \& Vascular Surgery | ISSN: 2572-7397

Journal Of Animal Research \& Veterinary Science | ISSN: 2639-375

Journal Of Aquaculture \& Fisheries | ISSN: 2576-5523

Journal Of Atmospheric \& Earth Sciences | ISSN: 2689-8780

Journal Of Biotech Research \& Biochemistry

Journal Of Brain \& Neuroscience Research

Journal Of Cancer Biology \& Treatment | ISSN: 2470-7546

Journal Of Cardiology Study \& Research | ISSN: 2640-768X

Journal Of Cell Biology \& Cell Metabolism | ISSN: 2381-1943

Journal Of Clinical Dermatology \& Therapy | ISSN: 2378-8771

Journal Of Clinical Immunology \& Immunotherapy | ISSN: 2378-8844

Journal Of Clinical Studies \& Medical Case Reports | ISSN: 2378-880

Journal Of Community Medicine \& Public Health Care | ISSN: 2381-1978

Journal Of Cytology \& Tissue Biology | ISSN: 2378-9107

Journal Of Dairy Research \& Technology | ISSN: 2688-9315

Journal Of Dentistry Oral Health \& Cosmesis | ISSN: 2473-6783

Journal Of Diabetes \& Metabolic Disorders | ISSN: 2381-201X

Journal Of Emergency Medicine Trauma \& Surgical Care | ISSN: 2378-8798

Journal Of Environmental Science Current Research | ISSN: 2643-5020

Journal Of Food Science \& Nutrition | ISSN: 2470-1076

Journal Of Forensic Legal \& Investigative Sciences | ISSN: 2473-733X

Journal Of Gastroenterology \& Hepatology Research | ISSN: 2574-2566
Journal Of Genetics \& Genomic Sciences | ISSN: 2574-2485

Journal Of Gerontology \& Geriatric Medicine | ISSN: 2381-8662

Journal Of Hematology Blood Transfusion \& Disorders | ISSN: 2572-2999

Journal Of Hospice \& Palliative Medical Care

Journal Of Human Endocrinology | ISSN: 2572-9640

Journal Of Infectious \& Non Infectious Diseases | ISSN: 2381-8654

Journal Of Internal Medicine \& Primary Healthcare | ISSN: 2574-2493

Journal Of Light \& Laser Current Trends

Journal Of Medicine Study \& Research | ISSN: 2639-5657

Journal Of Modern Chemical Sciences

Journal Of Nanotechnology Nanomedicine \& Nanobiotechnology | ISSN: 2381-2044

Journal Of Neonatology \& Clinical Pediatrics | ISSN: 2378-878X

Journal Of Nephrology \& Renal Therapy | ISSN: 2473-7313

Journal Of Non Invasive Vascular Investigation | ISSN: 2572-7400

Journal Of Nuclear Medicine Radiology \& Radiation Therapy | ISSN: 2572-7419

Journal Of Obesity \& Weight Loss | ISSN: 2473-7372

Journal Of Ophthalmology \& Clinical Research | ISSN: 2378-8887

Journal Of Orthopedic Research \& Physiotherapy | ISSN: 2381-2052

Journal Of Otolaryngology Head \& Neck Surgery | ISSN: 2573-010X

Journal Of Pathology Clinical \& Medical Research

Journal Of Pharmacology Pharmaceutics \& Pharmacovigilance | ISSN: 2639-5649

Journal Of Physical Medicine Rehabilitation \& Disabilities | ISSN: 2381-8670

Journal Of Plant Science Current Research | ISSN: 2639-3743

Journal Of Practical \& Professional Nursing | ISSN: 2639-568

Journal Of Protein Research \& Bioinformatics

Journal Of Psychiatry Depression \& Anxiety | ISSN: 2573-0150

Journal Of Pulmonary Medicine \& Respiratory Research | ISSN: 2573-0177

Journal Of Reproductive Medicine Gynaecology \& Obstetrics | ISSN: 2574-2574

Journal Of Stem Cells Research Development \& Therapy | ISSN: 2381-2060

Journal Of Surgery Current Trends \& Innovations | ISSN: 2578-7284

Journal Of Toxicology Current Research | ISSN: 2639-3735

Journal Of Translational Science And Research

Journal Of Vaccines Research \& Vaccination | ISSN: 2573-0193

Journal Of Virology \& Antivirals

Sports Medicine And Injury Care Journal | ISSN: 2689-8829

Trends In Anatomy \& Physiology | ISSN: 2640-7752

Submit Your Manuscript: https://www.heraldopenaccess.us/submit-manuscript 